\title{
PERLINDUNGAN HUKUM HAK KEKAYAAN INTELEKTUAL (HAKI) DALAM HAK CIPTA DI INDONESIA
}

Oleh:

\author{
Maya Jannah, SH, MH \\ Dosen Pengampu Mata kuliah Hak Kekayaan Intelektual \\ STIH Labuhanbatu \\ Email: maya_eriadihsb@yahoo.com
}

\begin{abstract}
ABSTRAK
Perlindungan hukum atas hak cipta telah diatur dalam undang-undang nomor 28 tahun 2014 tentang hak cipta. Hak Cipta termasuk ke dalam Hak atas kekayaan intelektual (HKI) yaitu merupakan hak atas kekayaan yang timbul dan lahir dari kemampuan intelektual manusia. Kemampuan tersebut dihasilkan oleh manusia dengan wujud karya-karya intelektual nya. Dalam Undang-Undang Nomor 28 tahun 2014 tentang hak cipta terlihat Implementasi perlindungan Hukum yang diberikan negara bagi pencipta.

Jenis penelitian yang digunakan adalah penelitian yuridis normatif. Peneltian ini menggunakan sumber data Sumber Bahan Hukum dalam Penelitian Normatif. teknik pengumpulan data dilakukan dengan cara library research.
\end{abstract}

Kata kunci: Perlindungan Hukum, Hak Kekayaan Intelektual, Hak Cipta.

\section{PENDAHULUAN}

Perkembangan kehidupan yang berlangsung sangat cepat terutama dibidang perekonomian baik ditingkat nasional maupun internasional ikut memberikan andil terhadap terjadinya perubahan dari Hak Kekayaan Intelektual (HAKI), khususnya dibidang Hak Cipta. Untuk itu diperlukan perlindungan hukum yang efektif terhadap hak cipta untuk mewujudkan iklim yang baik bagi tumbuh dan berkembangnya semangat mencipta dibidang ilmu pengetahuan, seni dan sastra.

Pengaturan mengenai Hak Cipta di Indonesia dimulai dengan berlakunya Auterswet 1912 (Stb. 1912 No. 600). Auterswet 1912 ini kemudian dicabut setelah pemerintah Indonesia berhasil menciptakan Hak Cipta Nasionalnya sendiri pada tahun
1982, yaitu dengan diundangkannya UndangUndang (UU) No. 6 tahun 1982 tentang "Hak Cipta” (LN 1982 No. 15 dan TLN No. 3217). Selanjutnya pada tahun 1987, UU Hak Cipta Tahun 1982 disempurnakan dengan UU No. 7 Tahun 1987 (LN No. 3362 dan TLN No. 3362). Kemudian UU No. 7 Tahun 1987 disempurnakan lagi dengan UU No. 12 Tahun 1997 (LN No. 29 dan TLN No. 2679) dan UU No. 12 Tahun 1997 digantikan UU No. 19 Tahun 2002 (LN NO. 85 dan TLN No. 4220), dan saat ini berlaku UU No. 28 Tahun 2014 (LN.2014/No. 266, TLN No. 5599, LL SETNEG: 57 HLM).

Berdasarkan Undang-undang No. 7

Tahun 1994 tentang Pengesahan Agreement Establishing The World Trade Organization (Persetujuan Pembentukan Organisasi 
Perdagangan Dunia), selanjutnya disingkat WTO, Indonesia menjadi peserta dari Organisasi Perdagangan Dunia. Konvensi ini berpengaruh besar terhadap berbagai sistem hukum nasional pada umumnya termasuk Indonesia dan hukum hak cipta pada khususnya.

Sebagai konsekuensi ikut sertanya Indonesia pada perjanjian WTO yang memuat Lampiran IC: Persetujuan TRIPs menimbulkan kebutuhan untuk menyempurnakan dan mengubah sekali lagi beberapa peraturan perundang-undangan bidang Hak Cipta yaitu UUHC 1987 melalui perundang-undangan baru berkenan dengan beberapa ciri-ciri pokok dan unsur-unsur yang dimaksud dalam Persetujuan TRIPs. Bentuknya berupa :

1. Memberlakukan Konvensi Bern 1971 yang belum berlaku bagi Indonesia;

2. Mencabut ketentuan-ketentuan Hak Cipta yang tidak sesuai dan menggantinya dengan yang sesuai dengan ketentuanketentuan Persetujuan TRIPs;

3. Menetapkan penambahan-penambahan ciptaan-ciptaan yang diatur dalam persetujuan TRIPs yang dinamakan hakhak yang berkaitan dengan Hak Cipta.

Karena itu berkenaan dengan Konvensi Bern 1971, Indonesia mau tidak mau wajib memenuhi ketentuan-ketentuan pasal 1-21 Konvensi Bern beserta lampiran-lampirannya, sebagaimana yang telah ditetapkan dalam Pasal 9 Persetujuan TRIPs :
1. Peserta-peserta Perjanjian wajib mematuhi ketentuan-ketentuan yang dimaksud dalam Pasal 1 sampai dengna Pasal 21 Konvensi Bern (1971) berikut Lampirannya. Pesertapeserta Perjanjian tidak mempunyai hak maupun kewajiban berdasarkan Persetujuan ini sepanjang mengenai hakhak yang diperoleh berdasarkan Pasal 6 bis dari Konvensi tersebut atau hak-hak yang timbul dari padanya.

2. Perlindungan terhadap Hak Cipta meliputi bentuk-bentuk perwujudan dan tidak meliputi ide, prosedur, metode kerja atau konsep sejenisnya.

Selanjutnya mengenai pengaturan "Pendaftaran", pada hak cipta, pengaruh Doktrin Hak Cipta Kontinental dapat diperhatikan pada penjelasan Undang-undang Hak Cipta yang menyatakan bahwa pendaftaran itu tidak mutlak harus dilakukan karena tanpa pendaftaran pun Hak Cipta dilindungi.

Doktrin Eropa Kontinental ini tidak mensyaratkan pendaftaran sebagai bukti hak karena Hak Cipta memperoleh perlindungan secara otomatis ketika hak cipta sudah terwujud ekspresi (expression), yang sudah dapat dilihat, dibaca, didengarkan dan sebagainya. Hukum hak cipta tidak melindungi ciptaan yang masih berupa ide (idea), yang berbeda dengan sistem perlindungan paten dan rahasia dagang (know how) yang melindungi ide.

Adapun hasil ciptaan seseorang yang termasuk dalam kategori ciptaan yang 
dilindungi disebutkan dalam Pasal Pasal 40 ayat (1) UUHC 2014 adalah :

a. Buku, pamflet, perwajahan karya tulis yang diterbitkan, dan semua hasil karya tulis lainnya:

b. Ceramah, kuliah, pidato, dan Ciptaan sejenis lainnya;

c. Alat peraga yang dibuat untuk kepentingan pendidikan dan ilmu pengetahuan;

d. Lagu dan/atau musik dengan atau tanpa teks;

e. Drama, drama musikal, tari, koreografi, pewayangan,dan pantomim;

f. Karya seni rupa dalam segala bentuk seperti lukisan,gambar, ukiran, kaligrafi, seni pahat, patung, atau kolase;

g. Karya seni terapan;

h. Karya arsitektur;

i. Peta;

j. Karya seni batik atau seni motif lain;

k. Karya fotografi;

1. Potret;

m. Karya sinematografi;

n. Terjemahan, tafsir, saduran, bunga rampai, basis data,adaptasi, aransemen, modifikasi dan karya lain darihasil transformasi;

o. Terjemahan, adaptasi, aransemen, transformasi, atau modihkasi ekspresi budaya tradisional;

p. Kompilasi Ciptaan atau data, baik dalam format yang dapat dibaca dengan Program Komputer maupun media lainnya;

q. Kompilasi ekspresi budaya tradisional selama kompilasi tersebut merupakan karya yang asli; r. Permainan video; dan

s. Program Komputer.

Menurut ketentuan Pasal 1 angka 1 UU No. 28 Tahun 2014 yang berbunyi : "Hak Cipta adalah hak eksklusif pencipta yang timbul secara otomatis berdasarkan prinsip deklaratif setelah suatu ciptaan diwujudkan dalam bentuk nyata tanpa mengurangi pembatasan sesuai dengan ketentuan peraturan perundangundangan".

Hak cipta adalah hak eksklusif yang diberikan suatu negara kepada pencipta yang baru diberikan negara dibidang ilmu pengetahuan, seni dan sastra yang mempunyai peranan strategis dalam mendukung pembangunan bangsa dan memajukan kesejahteraan umum sebagaimana diamanatkan oleh Undang-Undang Dasar Negara Republik Indonesia Tahun 1945.

Hak cipta terdiri dari hak ekonomi dan hak moral. Hak ekonomi adalah hak untuk mendapatkan manfaat ekonomi atas ciptaan produk serta produk hak terkait. Sedangkan hak moral adalah hak yang melekat pada diri pencipta yang tidak dapat dihilangkan tanpa alasan apapun walaupun hak tersebut telah dialihkan.

Berbeda dengan paten atau merek yang diwajibkan undang-undang untuk didaftarkan agar mendapatkan perlindungan hukum, hak cipta tidak diharuskan demikian. Hak Cipta boleh juga didaftarkan boleh juga tidak, karena ciptaan yang tidak didaftarpun mendapat perlindungan hukum. 
Tetapi jika suatu hak cipta itu didaftarkan akan lebih menguntungkan penciptanya sendiri, karena orang yang namanya terdaftar di Kantor Wilayah (Kanwil) Departemen Hukum dan Hak Asasi Manusia (Keputusan Menteri Kehakiman RI Nomor : M.09-PR.07.06 Tahun 1999) yang masih sebagai perpanjangan tangan dalam proses pendaftaran didaerah masing-masing, dianggap sebagai pencipta (sistem sentralisasi). Hal ini dapat memudahkan pembuktian-pembuktian jika terjadi sengketa.

Pendaftaran dalam Undang-undang Hak Cipta Indonesia dilakukan secara pasif atau disebut dengan sistem pendaftaran negatif deklaratif. Artinya, semua pendaftaran diterima dengan tidak terlalu mengadakan penelitian mengenai hak pemohon, kecuali jika ternyata ada pelanggaran hak cipta. Sistem pendaftaran ini titik beratnya diletakkan pada anggapan sebagai pencipta terhadap hak yang didaftarkan itu, sampai ada orang lain dapat membuktikan sebaliknya.

Ketentuan yang mengatur mengenai pelaksanaan pendaftaran ciptaan adalah Pasal 64 sampai dengan Pasal 73 UUHC Undangundang No. 28 Tahun 2014, Peraturan Menteri Kehakiman Nomor : M.01-HC.03.01 Tahun 1987 tentang "Pendaftaran Ciptaan" dan Peraturan Pemerintah (PP) No. 26 Tahun 1999 tentang "Tarif Atas Penerimaan Negara Bukan Pajak Yang Berlaku Pada Departemen Kehakiman”. PP No. 26 Tahun 1999 disempurnakan lagi dengan PP No. 75 Tahun 2005 dan PP No. 75 Tahun 2005 digantikan PP
No. 19 Tahun 2007 tentang "Jenis dan Tarif Atas Jenis Penerimaan Negara Bukan Pajak Yang Berlaku Pada Departemen Hukum dan Hak Asasi Manusia”.

Permohonan pendaftaran ciptaan diajukan kepada Menteri Hukum dan HAM (Hak Asasi Manusia) Republik Indonesia melalui Direktorat Jendera Hak Atas Kekayaan Intelektual (Dirjen HAKI) .

\section{PERMASALAHAN}

Yang menjadi permasalahan dalam penulisan ini adalah sebagai berikut: bagaimana Perlindungan Hukum Hak Kekayaan Intelektual (HaKI) dalam Hak Cipta di Indonesia?

\section{III.URAIAN TEORITIS}

\section{a. Sumber Hukum Hak Cipta dan}

\section{Ciptaan Yang Dilindungi}

1. Sumber Hukum Hak Cipta

a. Perundang-Undangan

Berdasarkan sejarah berlakunya hukum, Indonesia tergabung kedalam sistem hukum sipil "civil law" atau sistem hukum Eropa Kontinental, yang berasal dari tradisi hukum Romawi Jerman (Romano-Germanic). Didalam sistem hukum sipil ini sumber hukum pertama dan utama adalah produk legislatif berupa perundang-undangan (legislation), sementara sumber hukum lainnya seperti kebiasaan, putusan pengadilan (yurisprudensi), pendapat sarjana (doktrin) dan perjanjian antar negara (traktat) berlaku sebagai pelengkap. 
Pengertian perundang-undangan

(legislasi) disini dipakai dalam arti luas mencakup disamping undang-undang juga produk hukum lainnya dibawah undangundang (legislasi subordinasi) misalnya Peraturan Pemerintah, Keputusan Presiden, Keputusan Menteri dan sebagainya. Perundang-undangan positif tentang hak cipta meliputi, antara lain :

1. Undang-Undang Republik Indonesia No. 6 Tahun 1982 tentang Hak Cipta;

2. Undang-Undang Republik Indonesia No. 7 Tahun 1987 tentang Perubahan atas;

3. Undang-Undang No. 6 Tahun 1982 tentang Hak Cipta;

4. Undang-Undang Republik Indonesia No. 12 Tahun 1997 tentang Perubahan UndangUndang No. 6 Tahun 1982 tentang Hak Cipta sebagaimana telah diubah dengan Undang-Undang No. 7 tahun 1987;

5. Undang-Undang Republik Indonesia No. 19 Tahun 2002 tentang Perubahan UndangUndang No. 6 Tahun 1982 tentang Hak Cipta sebagaimana telah diubah dengan Undang-Undang Nomor 7 Tahun 1987 dan Undang-Undang No. 12 Tahun 1997;

6. Undang-Undang Republik Indonesia No. 28 Tahun 2014 tentang Perubahan UndangUndang No. 6 Tahun 1982 tentang Hak Cipta sebagaimana telah diubah dengan Undang-Undang Nomor 7 Tahun 1987 dan Undang-Undang No. 12 Tahun 1997 dan Undang-Undang Nomor 19 Tahun 2002;
7. Peraturan Pemerintah Republik Indonesia No. 14 tahun 1986 tentang Dewan Hak Cipta;

8. Peraturan Pemerintah Republik Indonesia No. 1 tahun 1987 tentang Penerjemahan dan/atau Perbanyak Ciptaan untuk Kepentingan Pendidikan, Ilmu Pengetahuan, Penelitian dan Pengambangan;

9. Peraturan Menteri Kehakiman Republik Indonesia No. M.01-HC.03.01 Tahun 1987 tentang Pendaftaran Ciptaan;

10. Keputusan Menteri Kehakiman Republik Indonesia NO. 04.PW.07.03 Tahun 1988 tentang Penyidik Hak Cipta.

11. Permenkumham No. 29 Tahun 2014 Tata Cara Permohonan Dan Penerbitan Izin Operasional Serta Evaluasi Lembaga Manajemen Kolektif;

12. Kepmenkumham No. HKI.20-T.03.01-04 Tahun 2015;

13. Kepmenkumham No. M.HH-01.HI.01.08 Tahun 2015;

14. Kepmenkumham No. HKI.2.OT.03.01-01 Tahun 2016.

Perundang-undangan hak cipta merupakan produk hukum tertulis dibidang hak cipta yang dikeluarkan oleh pejabat/lembaga yang berwenang untuk itu. Perundang-undangan ini adalah produk manusia yang tentunya tidaklah sempurna. Oleh karena itu selalu terdapat kekurangankekurangan yang perlu terus disempurnakan berdasarkan pengetahuan dan pengalaman 
untuk dapat menampung kebutuhankebutuhan baru akibat perkembangan kehidupan masyarakat diberbagai bidang.

Atas dasar itulah, UUHC Indonesia terus diubah dan ditambah untuk mengakomodasi kebutuhan-kebutuhan baru masyarakat. Beberapa kelemahan UUHC sebelumnya (1982 dan 1987) sudah dihilangkan atau disempurnakan dengan UUHC 1997 yang mulai berlaku pada bulan Mei 1997, sebagai berikut :

a. Perlindungan Terhadap Ciptaan Yang Tidak Diketahui Penciptanya.

Hal ini diatur dalam Pasal 10A UUHC yang menentukan bahwa negaralah yang memegang hak cipta atas ciptaan tersebut untuk kepentingan penciptanya, dengan jangka waktu perlindungan 50 tahun sejak karya cipta tersebut diketahui oleh masyarakat umum. Hak demikian perlu diatur, terutama dalam mengantisipasi kemungkinan adanya peniruan atau pelanggaran oleh pihak luar negeri, yang sebelumnya tidak jelas siapa yang berhak melakukan gugatan/tuntutan.

b. Pengecualian Pelanggaran Terhadap Hak Cipta

Pengaturannya terdapat dalam Pasal 14 UUHC yang menentukan bahwa dengan syarat sumbernya harus disebut atau dicantumkan, maka tidak dianggap sebagai pelanggaran Hak Cipta. Tindakan-tindakan tersebut antara lain sebagai berikut :

1) Penggunaan ciptaan hak lain untuk keperluan pendididikan, penelitian, penulisan karya ilmiah, penyusunan laporan, penulisan kritik dan tinjauan suatu masalah dengan ketentuan tidak merugikan kepentingan yang wajar bagi pencipta.

2) Pengambilan ciptaan pihak lain baik seluruhnya maupun sebagian guna keperluan pertunjukan atau pementasan yang tidak dipungut bayaran dengan ketentuan tidak merugikan kepentingan yang wajar bagi pencipta.

3) Perbanyak suatu ciptaan selain program komputer, secara terbatas dengan cara atau alat apapun atau proses yang serupa oleh Perpustakaan Umum, Lembaga Ilmu Pengetahuan atau Pendidikan dan Pusat Dokumentasi yang Non Komersial, semata-mata untuk keperluan aktivasinya.

c. Hak dan Kewenangan Menggugat Menyangkut hal ini pasal 14 UUHC Tahun 1997 menegaskan tentang adanya kewenangan menggugat pada pencipta berdasarkan hak moral, berkaitan dengan nilai yang bersifat non komersial, seperti pencantuman nama pencipta, walaupun secara ekonomis hak cipta tersebut telah diserahkan kepada pihak lain berdasarkan perjanjian lisensi. Sedangkan Pasal 42 sampai dengan 43B mengatur secara lebih rinci tentang prosedur dan hak pencipta untuk melakukan gugatan ganti rugi dan penyitaan benda objek pelanggaran hak cipta. 
d. Penyidik Pegawai Negeri Sipil (PPNS).

Pada pasal 47 diatur secara lebih jelas tentang wewenang PPNS dan hubungannya dengan Penyidik Umum POLRI, yang selama ini masih kabur pembatasan ruang lingkup tugas dan tanggungjawabnya.

e. Penyewaan Ciptaan

Pengaturan mengenai hak sewa merupakan hak baru dalam UUHC, sebagai konsekuensi berlakunya persetujuan TRIPs-WTO. Dalam pasal 3 UUHC Tahun 1997 ditegaskan bahwa pencipta Karya Film dan Program Komputer serta produser rekaman suara mempunyai hak untuk memberi izin atau melarang orang lain menyewakan secara komersial atas karya ciptaannya. Oleh karena itu, perusahaanperusahaan penyewa "VCD" dan "Computer Rental" harus membayar Royalti atau meminta izin atau membuat perjanjian lisensi terlebih dahulu dengan pencipta atau produsen rekaman suara sebelum melakukan transaksi penyewaan kepada konsuman akhirnya.

f. Hak-Hak Yang Berkaitan Dengan Hak Cipta (Neighbouring Rights)

Apabila hak cipta diberikan kepada pencipta, hak yang berkaitan dengan hak cipta in diberikan khusus kepada (a) Pelaku (Artis, Aktor, Penyanyi, Penari dan semacamnya), (b) Produser Rekaman Suara, dan (c) Lembaga Penyiaran. Pengaturan inipun merupakan penambahan baru sebagaimana sebelumnya telah diatur dalam Konvensi Roma dan TRIPs-WTO.
Dalam UUHC Tahun 1997 ketentuan demikian ditampung bahwa karena kemungkinan adanya kerugian ekonomis dan kerugian lain yang timbul karena pelanggaran "Neighbouring Rights" ini pada dasarnya sama denganhak cipta, maka pengaturan sanksi pun disamakan dengan sanksi pelanggaran hak cipta. Menyangkut dnegan jangka watu perlindungannya diatur secara khusus pada Pasal 43D UUHC.

\section{g. Lisensi Hak Cipta}

Lisensi merupakan kontrak yang dibuat oleh pemilik dan pengguna hak cipta. Kontrak ini pada dasarnya berisi pemberian izin untuk mengunakan hak cipta, biasanya untuk tujuan komersial yang disertai penentuan jumlah dan cara pembayaran royalti. Lisensi ini diatur dalam Pasal 38 A, 38B dan 38C, sebagai aturan pokok, selebihnya akan diatur dalam peraturan pemerintah. UUHC mewajibkan penatatan lisensi itu di Kantor Hak Cipta dan isinya tidak boleh memuat ketentuan yang langsung atau yang tidak langsung dapat menimbulkan akibat yang merugikan perekonomian Indonesia. Untuk itu, Kantor Hak Cipta berwenang menolak pencatatan apabila memuat ketentuan diatas.

b. Yurisprudensi

Perkembangan pembentukan hukum hak cipta melalui yurisprudensi belum begitu berkembang di Indonesia. Penyebabnya antara lain adalah belum banyaknya kasus-kasus yang masuk ke Pengadilan dan belum baiknya 
sistem informasi hukum sehingga sulit sekali mencari dan menemukan kembali kasus-kasus yang pernah diputus pengadilan diseluruh wilayah tanah air yang cukup luas ini. Disamping sebagai konsekuensi dianutnya sistem hukum sipil, penghargaan hakim terhadap yurisprudensi juga lemah. Di Indonesia putusan hakim terlebih dahulu ini tidak mengikat, artinya hakim terdahulu ini tidak mengikat, artinya hakim bebas untuk memakai atau tidaknya sebagai sumber hukum didalam mengadili suatu perkara.

c. Konvensi Internasional

Beberapa perjanjian bilateral hak cipta yang telah diratifikasi Indonesia adalah :

(1) Keputusan Presiden Republik Indonesia No. 17 Tahun 1988 tetnang Pengesahan Persetujuan Pemerintah RI dengan Masyarakat Eropa mengenai pemberian Perlindungan Hukum secara Timbal Balik Atas Rekaman Suara (Sound Recordings).

(2) Keputusan Presiden Republik Indonesia No. 25 Tahun 1989 tentang Ratifikasi Persetujuan Perlindungan Hak Cipta antara RI dengan Amarika Serikat.

(3) Keputusan Presiden Republik Indonesia No. 38 Tahun 1993 tentang Rantifikasi Persetujuan Perlindungan Hak Cipta Antara RI dan Inggris.

Disamping perjanjian bilateral, terdapat juga perjanjian multilateral, antara lain :

(1) Undang-Undang Republik Indonesia No. 7 tahun 1994 tentang Pengesahan Persetujuan Pembentukan Organisasi
Perdagangan Dunia (Agreement

Establishing the Worl Trade

Organization).

(2) Keputusan Presiden Republik Indonesia No. 18 Tahun 1997 tentang Pengesahan Konvensi Bern (Bern Convention for the Protection of Literary and Artistic Works).

(3) Keputusan Presiden Republik Indonesia No. 15 Tahun 1997 tentang Pengesahan Organisasi WIPO (WIPO Copyright Treaty).

(4) Keputusan Presiden Nomor 74 Tahun 2004 Tentang World Intellectual Property Organization Performances and Phonograms Treaty (Perjanjian KaryaKarya Pertunjukan dan Karya-Karya Fonogram WIPO) yang selanjutnya disebut WPPT.

Untuk dapat mendukung kegiatan pembangunan nasional, terutama dengan memperhatikan berbagai perkembangan dan perubahan, Indonesia yang sejak tahun 1982 telah memiliki Undang-undang tentang Hak Cipta Nasional yang kemudian disempurnakan dengan Undang-Undang No. 7 Tahun 1987 dan disempurnakan lagi dengan UndangUndang No. 12 Tahun 1997 perlu mengganti Undang-Undang tersebut agar sesuai dengan standar yang ditentukan dalam Konvensi Internasional tersebut.

Dibandingkan dengan Undang-Undang No. 6 Tahun 1982 tentang Hak Cipta sebagaimana telah diubah dengan UndangUndang No. 7 Tahun 1987 dan UndangUndang No. 12 Tahun 1997, Undang-Undang 
No. 19 Tahun 2002 dan terakhir Undangundang No. 28 Tahun 2014 menunjukkan perbedaan antara lain :

1. Lingkup Ciptaan yang mendapat perlindungan disempurnakan, yaitu karyakarya pertunjukan dan karya siaran dihapuskan dari ciptaan yang dilindungi dan hanya mendapat perlindungan dalam hak yang berkaitan dengan hak cipta. Hal ini dilaksanakan untuk tidak menimbulkan kebingungan kedua karya itu dilindungi oleh hak cipta dan juga oleh hak terkait (Neighbouring Rights).

2. Demikian pula kreasi intelektual database dimasukkan menjadi salah satu ciptaan yang dilindungi sebagaimana diamanatkan WIPO Copyright Treaty (WCT), dimana Indonesia telah menandatangani perjanjian tersebut.

3. Dimuatnya ketentuan tentang penggunaan alat apapun baik melalui kabel maupun tanpa kabel, termasuk media internet, untuk pemutaran produk-produk cakram optik (optical disc) melalui media audio, media audio visual dan/atau sarana telekomunikasi.

4. Dalam masalah penyelesaian sengketa, undang-undang ini menetapkan penyelesaiannya oleh Pengadilan Niaga dan juga disediakannya pilihan penyelesaian melalui Alternatif Penyelesaian Sengketa seperti Arbitrase, Mediasi dan sejenisnya.

5. Hal lain yang ditambahkan dalam undangundang ini adalah diperkenalkannya sistem penetapan sementara pengadilan sebagaimana diamanatkan dalam Article 50 TRIPs, sehingga memungkinkan pencegahan lebih jauh akan kerugian dari pemegang hak, dan juga secara seimbang menjaga kepentingan pihak yang dikenakan penetapan sementara pengadilan.

6. Penambahan lain adalah ditetapkannya ancaman pidana atas pelanggaran hak terkait, yang dalam Undang-Undang Hak Cipta sebelumnya ancaman pidana tersebut hanya berlaku secara mutatis mutandis.

7. Penambahan ketentuan pidana minimal dan maksimal dalam undang-undang ini dimaksudkan untuk menangkal terhadap pelanggaran hak cipta sehingga diharapkan efektivitas penindakannya akan terwujud.

8. Pembatasan waktu proses perkara dibidang hak cipta yang ditangani oleh Pengadilan Niaga maupun Mahkamah Agung hal ini untuk memberikan kepastian hukum dan mencegah berlarut-larutnya penanganan suatu perkara dibidang hak cipta yang mempunyai akibat sangat luas dibidang ekonomi dan perdagangan.

9. Penambahan kententuan mengenai informasi manajemen elektronik dan sarana kontrol teknologi dimaksudkan untuk menyesuaikan dengan ketentuan dalam WIPO Copyright Treaty (WTC).

\section{Ciptaan Yang Dilindungi}

Menurut L. J. Taylor, yang dilindungi hak cipta adalah ekspresinya dari sebuah ide, juga bukan melindungi idenya itu sendiri. Dengan demikian yang dilindungi adalah 
sudah dalam bentuk nyata sebagai sebuah ciptaan bukan masih merupakan gagasan. Bentuk nyata tersebut bisa terwujud khas dalam bidang kesusteraan, seni maupun ilmu pengetahuan. Konvensi Internasional Hak Cipta 1955 (UCC), pada Pasal 1, menentukan yang dilindunginya adalah bidang kesusteraan, ilmu pengetahuan (scientific), dan pekerjaan seni (artistic work) termasuk karya tulis, musik, drama, sinematografi, lukisan, pahatan dan patung.

Bidang-bidang yang dilindungi hak cipta berdasarkan ketentuan Pasal 40 ayat (1) UUHC 2014 adalah :

a. Buku, pamflet, perwajahan karya tulis yang diterbitkan, dan semua hasil karya tulis lainnya:

b. Ceramah, kuliah, pidato, dan Ciptaan sejenis lainnya;

c. Alat peraga yang dibuat untuk kepentingan pendidikan dan ilmu pengetahuan;

d. Lagu dan/atau musik dengan atau tanpa teks;

e. Drama, drama musikal, tari, koreografi, pewayangan,dan pantomim;

f. Karya seni rupa dalam segala bentuk seperti lukisan,gambar, ukiran, kaligrafi, seni pahat, patung, atau kolase;

g. Karya seni terapan;

h. Karya arsitektur;

i. Peta;

j. Karya seni batik atau seni motif lain;

k. Karya fotografi;

1. Potret;

m. Karya sinematografi; n. Terjemahan, tafsir, saduran, bunga rampai, basis data,adaptasi, aransemen, modifikasi dan karya lain darihasil transformasi;

o. Terjemahan, adaptasi, aransemen, transformasi, atau modihkasi ekspresi budaya tradisional;

p. Kompilasi Ciptaan atau data, baik dalam format yang dapat dibaca dengan Program Komputer maupun media lainnya;

q. Kompilasi ekspresi budaya tradisional selama kompilasi tersebut merupakan karya yang asli;

r. Permainan video; dan

s. Program Komputer.

Secara garis besarnya bidang yang dilindungi hak cipta dapat digolongkan menjadi tiga, yaitu :

1. Meliputi pekerjaan yang ditentukan dalam Konvensi Bern, yaitu bidang kesusasteraan (literary), pekerjaan artistik (artistic work), termasuk pula drama, musik dan drama musikal.

2. Kategori yang muncul belakangan karena perkembangan teknologi, yaitu seperti sinematografi, fotografi, rekaman suara, penyiaran (broadcasting) baik radio maupun televisi.

3. Kelompok yang berhubungan dengan komputer, yaitu : Mengenai program komputer. Di Prancis program komputer ini mulai dilindungi pada tahun 1985, di Inggris diatur dalam Cipyright Amandement Act 1985, di Amerika Serikat diatur dalam Computer Softwar Copyright Act 1980 dan di Indonesia 
diatur dalam Undang-Undang Hak Cipta 1987.

\subsection{Maksud dan Tujuan Pendaftaran Hak}

\section{Cipta}

1. Maksud Pendaftaran Hak Cipta

Ciptaan tidak kalah pentingnya dengan benda-benda lain seperti tanah, kendaraan bermotor, kapal, merek yang memerlukan pendaftaran. Pendaftaran ciptaan dimaksudkan hanya untuk mendaftarkan ciptaan secara formal saja. Dirjen HAKI tidak meneliti secara material setiap ciptaan yang didaftarkan. Hal ini didasarkan pada uraian yang menyatakan bahwa pendaftaran tidak mutlak untuk mendapatkan hak cipta. Lagi pula Undangundang sudah menganggap pengumuman pertama suatu ciptaan merupakan pendaftaran hak cipta.

2. Tujuan Pendaftaran Hak Cipta

Setiap orang yang mendaftarkan ciptaannya mempunyai tujuan agar ciptaannya mendapat perlindungan hukum. Apabila suatu ciptaan sudah didaftarkan, surat-surat pendaftaran yang dikeluarkan Direktorat Jenderal akan lebih mudah membuktikan siapa penciptanya. Pada Pasal 31 UUHC Tahun 2014 ditetapkan, orang yang namanya tercantum dalam Daftar Umum Ciptaan dianggap sebagai penciptanya (kecuali ada pihak lain dapat membuktikan sebaliknya). Dengan demikian, ciptaan yang tidak didaftarkan akan lebih sulit dan lebih memakan waktu untuk membuktikan hak ciptanya.

\section{IV.PEMBAHASAN}

\section{a. Syarat-Syarat Pendaftaran Hak Cipta}

Salah satu perbedaan yang dianggap cukup penting antara Auterswet 1912 dengan UUHC Indonesia adalah perihal pendaftaran hak cipta. Auterswet 1912 sama sekali tidak mencantumkan pendaftaran hak cipta.

Menurut Kollewijn sebagaimana dikutip R. Sukardono mengatakan ketika memberikan advis kepada pengurus perkumpulan importir di Batavia dahulu (sub 2 a advis beliau, advis selengkapnya dimuat dalam T. 124 halaman 357 dan seterusnya) Ada dua jenis cara atau stelsel pendaftara, yaitu stelsel konstitutif dan stelsel deklaratir. Yang pertama, berarti bahwa hak cipta atas ciptaan baru terbit karena pendaftaran yang telah mempunyai kekuatan. Yang kedua bahwa pendaftaran yang telah mempunyai kekuatan. Yang kedua ialah bahwa pendaftaran itu bukanlah menerbitkan hak, melainkan hanya memberikan dugaan atau sangkaan saja menurut undang-undang bahwa orang yang hak ciptanya terdaftar itu adalah si berhak sebenarnya sebagai pencipta dari hak yang didaftarkannya.

Dalam stelsel konstitusif letak titik berat ada tidaknya hak cipta tergantung pada pendaftarannya. Jika didaftarkan (dengan sistem konstitutif) hak cipta itu diakui keberadaannya secara de jure dan de facto, sedangkan pada stelsel dekraratif titik beratnya diletakkan pada anggapan sebagai pencipta terhadap hak yang didaftarkan itu, sampai ada orang lain dapat membuktikan sebaliknya. 
Dengan kata lain, pada sistem deklaratif sekalipun hak cipta itu didaftarkan undangundang banyak mengakui seolah-oleh yang bersangkutan sebagai pemiliknya, secara de jure harus dibuktikan, jika ada orang lain yang menyangkal hal tersebut.

Selama orang lain tidak dapat membuktikan secara yuridis bahwa itu adalah haknya, maka si pendaftar dianggap satusatunya orang yang berhak atas ciptaan yang terdaftar dan setiap pihak ketiga harus menghormati haknya sebagai hak mutlak.

Dalam sistem pendaftaran hak cipta menurut perundang-undangan Hak Cipta Indonesia disebutkan bahwa pendaftaran ciptaan dilakukan secara pasif, artinya bahwa semua permohonan pendaftaran diterima dengan tidak terlalu mengadakan penelitian mengenai hak pemohon, kecuali sudah jelas ada pelanggaran hak cipta.

Pendaftaran hak cipta, tidak berarti secara subtantif Dirjen HAKI bertanggung jawab atas kebenaran (sebagai pemilik) karya cipta tersebut. Ketentuan ini sangat penting. Boleh jadi sebagian kecil dari karya cipta itu benar hasil ciptaannya, tetapi sebagian yang lain "dibajak" atau ditiru dari karya cipta orang lain. Dalam keadaan seperti ini Dirjen HAKI tidak memasukkan hal semacam ini sebagai bagian yang harus ditanggung jawabnya. Sistem pendaftaran deklaratif tidak mengenal pemeriksaan substantif, yakni pemeriksaan terhadap objek atau materi ciptaan yang akan didaftarkan tersebut.
Selanjutnya dapat dipahami bahwa fungsi pendaftaran hak cipta dimaksudkan untuk memudahkan pembuktian dalam hal terjadi sengketa mengenai hak cipta. Pendaftaran ini tidak mutlak diharuskan, karena tanpa pendaftaran pun hak cipta sudah dilindungi. Hanya mengenai ciptaan yang tidak didaftarkan akan lebih sukar dan lebih memakan waktu dalam pembuktiannya.

Dari penjelasan diatas dapat disimpulkan bahwa pendaftaran itu bukanlah syarat untuk sahnya (diakui) suatu hak cipta, melainkan untuk memudahkan suatu pembuktian bila terjadi sengketa. Itu artinya orang yang mendaftarkan hak cipta untuk pertama kalinya tidak berarti sebagai pemilik hak yang sah karena jika ada orang lain yang dapat membuktikan bahwa itu adalah haknya, maka kekuatan hukum dari suatu pendaftaran ciptaan tersebut dapat dihapuskan. Untuk itu pencipta dapat mengajukan gugatan ganti rugi, meminta penyitaan, menyerahkan seluruhnya atau sebagian penghasilan yang diperoleh dari pelanggaran hak cipta, menghentikan kegiatan pengumuman, perbanyak, pengedaran dan penjualan ciptaan atau barang yang merupakan hasil pelanggaran hak cipta. Gugatan tersebut dapat diajukan melalui pengadilan niaga yang saat ini ditempatkan dibawah Pengadilan Negeri.

Ketentuan lain yang membuktikan bahwa UUHC Indonesia menganut sistem pendaftaran deklaratif dapat dilihat dari bunyi Pasal 31 yang menyatakan bahwa "Kecuali 
terbukti sebaliknya, yang dianggap sebagai pencipta,yaitu Orang yang namanya:

a. disebut dalam Ciptaan;

b. dinyatakan sebagai Pencipta pada suatu Ciptaan;

c. disebutkan dalam surat pencatatan Ciptaan; dan/atau

d. tercantum dalam daftar umum Ciptaan sebagai pencipta.

Hal yang lebih penting lagi dari pendaftaran ini adalah dengan pendaftaran diharapkan dapat memberikan semacam kepastian hukum serta lebih memudahkan dalam prosedur pengalihan haknya. Bahkan menurut Mariam Darus, pendaftaran itu tidak hanya semata-mata mengandung arti untuk memberikan alat bukti yang kuat, akan tetapi juga menciptakan hak kebendaan. Hak kebendaan atas suatu benda untuk umum terjadi pada saat pendaftaran itu dilakukan. Selama pendaftaran belum terjalin, hak hanya mempunyai arti terhadap para pihak pribadi dan umum dianggap belum "mengetahui" perubahan status hukum atas hak yang dimaksudkan. Pengakuan dari masyarakat baru terjadi pada saat hak tersebut (milik) didaftarkan.

Pendaftaran dimaksud diselenggarakan oleh Dirjen HAKI dibawah naungan Departemen Hukum dan HAM dan dicantumkan dalam Daftar Umum Ciptaan yang dapat dilihat oleh semua orang. Mengenai cara pendaftaran akan diatur tersendiri dan diserahkan pengaturan selanjutnya melalui keputusan Presiden. Permohonan pendaftaran ciptaan dapat diajukan oleh pencipta atau pemegang hak cipta kepada Dirjen HAKI dengan surat rangkap dua dan ditulis dalam bahasa Indonesia dan disertai biaya pendaftaran dan contoh ciptaan atau penggantinya.

UUHC Indonesia ini juga berlaku terhadap ciptaan yang bukan Warga Negara Indonesia (WNI) dan Badan Hukum Asing, maka pernyataan surat permohonan harus ditulis dalam bahasa Indonesia. Hal ini dimaksudkan untuk memudahkan dalam proses pendaftaran sehingga tidak ditemukan penafsiran lain sesuai kehendak pemohonnya, sehingga orang asing hanya akan mendapat perlindungan bila telah memenuhi persyaratan yang ditentukan atau sesuai dengan suasana hukum nasional Indonesia, sesuai dengan prosedur buku yang ditetapkan dalam peraturan perundangan Indonesia. Tentu saja dimaksudkan demi kepastian hukum dan tidak ada sengketa dibelakang hari karena kekeliruan penafsiran bahasa, jika pendaftaran itu diperkenankan menurut bahasa negara masing-masing sesuai dengan negara asal penciptanya.

Atas dasar permohonan tersebut, Dirjen HAKI memuat catatan-catatan dan mencantumkannya dalam daftar umum ciptaan sebagaimana ditentukan dalam Pasal 69 catatan yang dicantumkan dalam daftar umum ciptaan antara lain : Nama Pencipta dan Pemegang Hak Cipta, Tanggal Penerimaan Surat Permohonan, Tanggal Lengkap 
Persyaratan (Surat Permohonan) dan Nomor Pendaftaran Ciptaan.

Sesuai dengan sifatnya, hak cipta ini dapat beralih dan dialihkan, maka pemilik hak cipta itu juga dapat berubah-ubah atau berpindah. Itu akan menyebabkan dalam daftar umum ciptaan akan berubah nama, alamat dan sebagainya. Perubahan ini akan dicatat dalam Berita Resmi Ciptaan. Ketentuan ini diatur dalam Pasal 78 ayat 1 dan 2 UUHC Indonesia. Satu hal yang perlu dicatat bahwa dalam pemindahan hak atas pendaftaran ciptaan yang didaftar dalam satu nomor hanya diperkenankan jika seluruh ciptaan yang terdaftar itu dipindahkan haknya kepada penerima hak. Maksudnya tidak boleh sebagian saja dari ciptaan yang didaftarkan dalam satu nomor pendaftaran itu dialihkan. Ciptaan yang dialihkan itu harus totalitas, utuh dan tidak boleh dipecah-pecah. Selanjutnya dalam Pasal 74 UUHC menyebutkan tentang hapusnya kekuatan hukum pendaftaran hak cipta dapat disebabkan oleh beberapa hal yaitu:

a. permintaan orang atau badan hukum yang namanyatercatat sebagai Pencipta, Pemegang Hak Cipta, ataupemilik Hak Terkait;

b. lampaunya waktu sebagaimana dimaksud dalam Pasa158, Pasal 59, Pasal 60 ayat (2) dan ayat (3), dan Pasal 61;

c. putusan pengadilan yang telah memperoleh kekuatanhukum tetap mengenai pembatalan pencatatan Ciptaan atau produk Hak Terkait; atau d. melanggar norma agama, norma susila, ketertibanumum, pertahanan dan keamanan negara, atau peraturan perundang-undangan yang penghapusannya dilakukan oleh Menteri.

Demikianlah syarat-syarat pendaftaran hak cipta yang dikemukakan diatas dimaksudkan, bahwa dengan pendaftaran lahirnya pengakuan secara de jure antara hak dengan bendanya. Tapi perlu dicatat, pendaftaran tidak merupakan suatu keharusan untuk terbitnya Hak Cipta. Ini adalah konsekuensi logis dari sistem Pendaftaran Deklaratif.

\section{b. Prosedur Pendaftaran Hak Cipta}

Berdasarkan Peraturan Menteri Kehakiman RI No. M.01-HC.03.01 Tahun 1987 tentang Pendaftaran Hak Ciptaan, bahwa permohonan pendaftaran ciptaan dilanjutkan kepada Menteri Kehakiman RI melalui Dirjen HAKI dengan :

1. Mengisi Formulir Pendaftaran Ciptaan :

a. Rangkap 3 (tiga);

b. Diatas kertas folio berganda;

c. Ditulis dalam Bahasa Indonesia;

d. Lembar pertama dibubuhi materai Rp. 6.000 (enam ribu rupiah);

e. Ditandatangani oleh pemohon atau kuasanya.

2. Formulir Pendaftaran, dilampiri :

a. Contoh ciptaan atau penggantinya;

b. Surat Kuasa Khusus;

c. Bukti Kewarganegaraan Pencipta dan Pemegang Hak Cipta atau Kuasanya; 
d. Salinan resmi Akta Pendirian Badan Hukum;

e. Bukti Pemindahan Hak;

f. Fotocopy Nomor Pokok Wajib Pajak (NPWP);

g. Membayar biaya pendaftaran.

3. Berkas Permohonan kemudian diolah dalam arti :
a. Diperiksa
kelengkapan
administrasi/Formalitas;
b. Diperiksa substantifnya;
c. Diperiksa oleh Tim Evaluasi Hak Cipta;

d. Dimohonkan persetujuan kepada Dirjen HAKI untuk didaftar atau ditolak;

e. Permohonan yang didaftar diterbitkan surat pendaftaran ciptaan, sedangkan permohonan yang ditolak dibuat surat permohonan dengan diserta alasannya. Baik surat pendaftaran didaftar maupun surat penolakan disampaikan kepada pemohon;

f. Ciptaan yang sudah terdaftar kemudian dicatat dalam Daftar Umum Ciptaan dan diumumkan dalam Tambahan Berita Negara (TBN) RI.

Sedangkan dalam proses pendaftaran hak cipta, maka pencipta/pemengang hak cipta atau kuasa mula-mula membawa persyaratan administrasi dengan mengajukan permohonan pendaftaran di loket pendaftaran ciptaan. Kemudian pemohon membayar biaya permohonan ke kasir yang besarnya tergantung pada ciptaan yang dimohonkan sesuai dengan Peraturan Pemerintah No. 19 Tahun 2007 tentang Jenis dan Tarif atas jenis penerimaan negara bukan pajak yang berlaku pada Departemen Hukum dan HAM dan membayar pembelian map.

Setelah itu pemohon diberi Surat Penerimaan Pendaftaran Ciptaan dan Permohonan tersebut diperiksa kelengkapan persyaratan administrasi yang biasa disebut Pemeriksaan Formalis atau Administrasi. Dan jika pada syarat administrasi tersebut terdapat keraguan, misalnya KTP (Kartu Tanda Penduduk) sudah kadaluarsa atau alamat dalam KTP/NWPW tidak sesuai dengan yang ada dalam Formulir Permohonan, maka pemohon diberitahukan secara tertulis untuk melengkapinya dan apabila dalam jangka waktu 3 (tiga) bulan ternyata tidak dilengkapi, maka permohonan batal demi hukum.

Terhadap permohonan yang telah memenuhi proses syarat administrasi selanjutnya dilakukan pemeriksaan substansif. Setelah selesai pemeriksaan substansif kemudian bekas disampaikan ke Tim Evaluasi Hak Cipta melalui Direktur Hak Cipta, Desain Industri, Desain Tata Letak Sirkuit Terpadu (DTLST) dan Rahasia Dagang, dan oleh Tim Evaluasi berkas permohonan diperiksa baik persyaratan formalitas maupun substantif.

Setelah selesai pemeriksaan berkas permohonan kemudkan dimohon persetujuan dari Direktorat Jenderal HAKI, apakah permohonan akan didaftar atau ditolak. Permohonan yang didaftar, selanjutnya oleh 
Sub. Dit. Permohonan dan Pengolahan diterbitkan Surat Pendaftaran Ciptaan dan ditandatangani oleh Dirjen HAKI.

Surat Pendaftaran Ciptaan yang telah ditandatangani, selanjutnya lembar kedua disampaikan ke Pemohon, sedangkan lembar pertama dicatat dalam Daftar Umum Ciptaan dan diumumkan dalam TBN (Tambahan Berita Negara).

Terhadap permohonan yang ditolak, selanjutnya dibuatkan surat penolakan yang ditandatangan Direktur Hak Cipta, Desai Industri, DTLST dan Rahasia Dagang dan disampaikan kepada pemohon. Pemohon tersebut dapat mengajukan keberatan ke Pengadilan Niaga, dalam jangka waktu 3 (tiga) bulan setelah diterimanya penolakan tersebut oleh pemohon atau kuasanya.

UUHC No. 28 Tahun 2014 tentang Hak Cipta bertujuan untuk mendorong dan melindungi para pencipta dalam bidang Ilmu Pengetahuan, seni dan sastra, dalam rangka meningkatkan kecerdasan banga Indonesia. Sekaligus sebagai penyempurna Undangundang yang lama, karena Undang-undang No.19 Tahun 2002 sudah tidak sesuai dengan perkembangan hukum dan kebutuhan masyarakat sehingga perlu diganti dengan Undang-Undang yang baru.

\section{KESIMPULAN}

Berdasarkan hal-hal yang telah diuraikan dan disampaikan sebelumnya, dapat ditarik kesimpulan sebagai berikut : a. Perlindungan Hukum HaKI dalam Hak Cipta di Indonesia sudah dimuat dalam UU No. 7 Tahun 1987 (LN No. 3362 dan TLN No. 3362). Kemudian disempurnakan lagi dengan pada UU No. 12 Tahun 1997 (LN No. 29 dan TLN No. 2679) dan disempurnakan lagi melalui UU No. 12 Tahun 1997 kemudian diperbaharui lagi dengan UU No. 19 Tahun 2002 (LN NO. 85 dan TLN No. 4220), dan saat ini berlaku UU No. 28 Tahun 2014 (LN.2014/No. 266, TLN No. 5599, LL SETNEG: 57 HLM). Hal ini sebagai wujud nyata negara dalam memberikan perlindungan terhadap hasil karya pencipta di Indonesia.

b. Kecuali terbukti sebaliknya, yang dianggap sebagai pencipta, yaitu Orang yang namanya: disebut dalam Ciptaan; dinyatakan sebagai Pencipta pada suatu Ciptaan; disebutkan dalam surat pencatatan Ciptaan; dan/atau tercantum dalam daftar umum Ciptaan sebagai pencipta.

b. pendaftaran hak cipta memberikan kepastian hukum bagi pencipta serta lebih memudahkan dalam prosedur pengalihan haknya selain itu, pendaftaran hak cipta tidak hanya semata-mata mengandung arti untuk memberikan alat bukti yang kuat, akan tetapi juga menciptakan hak kebendaan.

\section{DAFTAR PUSTAKA}

Ali, Achmad, Menguak Tabir Hukum (Suatu Kajian Filosofi dan Sosiologis), Jakarta : PT. Gunung Agung. 2002. 
Aman, Nurlely, Perlindungan Hukum Terhadap Pemegang Hak Cipta dan Penerbit, Medan ;PPs-Mkn Universitas Sumatear Utara, 2004.

Anwar, Dessy, Kamus Besar Bahasa Indonesia, Surabaya : Surya Abditama, 2001. Ashshofa, Burhan, Metode Penelitian Hukum, Jakarta : Rineka Cipta, 1994.

Bintang, Sanusi, Hukum Hak Cipta, Bandung : PT. Citra Aditya Bakti, 1998. Chandra, Robby I., Etika Dunia Bisnis, Yogyakarta : Kanisius, 1995.

Cotterel, Leslie E., Performance, The Business And Law Of Entertainment, Third Edition, London : Sweet and Maxwell, 1993.

Damian, Eddy, Hukum Hak Cipta Menurut Beberapa Konvensi Internasional, Undang-Undang Hak Cipta 1997 dan Perlindungannya Terhadap Buku Serta Perjanjian Penerbitannya, Bandung : Alumni, 1999.

Djumhana, Muhammad dan R. Djubaedillah, Hak Milik Intelektual (Sejarah Teori dan Prakteknya di Indonesia), Bandung : PT. Citra Aditya Bakti, 1997.

Hutauruk, M, Peraturan Bisnis Melalui Merek Paten dan Hak Cipta, Bandung : PT. Citra Aditya Bakti, 1997.

Kansil, C.S.T., Pengantar Ilmu Hukum dan Tata Hukum Indonesia, Jakarta : Balai Pustaka, 1980.

Lindsey, Tim, dkk, Hak Kekayaan Intelektual; Suatu Pengantar, Bandung : Alumni, 2003.

Mahadi, Hak Milik Immaterial, Jakarta : BPHN, 1985.

, Hak Milik Dalam Sistem Hukum Perdata Nasional, Jakarta : BPHN, 1981.
Margono, Suyud dan Amir Angkasa, Komersial Asset Intelektual Aspek Hukum Bisnis, Jakarta : PT. Gramedia Widiasarana Indonesia, 2002.

Maulana, Insan Budi, Sukses Bisnis Melalui Merek, Paten dan Hak Cipta, Bandung : PT. Citra Aditya Bakti, 1997.

Muhammad, Abdul Kadir, Hukum Harta Kekayaan, Bandung : PT. Citra Aditya Bakti, 2001.

, Kajian Hukum Ekonomi Hak Kekayaan Intelektual, Bandung : PT. Citra Aditya Bakti, 2001.

Purba, Afrillyana, dkk., TRIPS-WTO dan Hukum HKI Indonesia; Kajian Perlindungan Hak Cipta Seni Batik Tradisional Indonesia, Jakarta : PT. Rineka Cipta, 2005.

Rahardjo, Satjipto, Ilmu Hukum, Bandung : PT. Citra Aditya Bakti, 2000.

Remaja Rosdakarya, 1993.

Saidin, OK., Aspek Hukum Hak Kekayaan Intelektual (Intellectual Property Rights), Jakarta : PT. Raja Grafindo Persada, 2007.

Simorangkir, J.C.T., Undang-Undang Hak Cipta 1982, Jakarta : PT. Djamatan, 1982.

Soekanto, Sujono, Pengantar Penelitian Hukum, Jakarta : UI Press, 1986.

Sofyan, Sri Soedwei Masjchoen, Hukum Perdata; Hukum Benda, Yogyakarta : Liberty, 1981.

Sunggono, Bambang, Metode Penelitian Hukum, Jakarta : PT. Raja Grafindo Persada, 2003.

Syarifin, Pipin dan Dedah Jubaedah, Peraturan Hak Kekayaan Intelektual di Indonesia, Bandung : Pustaka Bani Quraisy, 2000. 
Usman, Rahomadi, Hukum Hak Atas Kekayaan Intelektual (Perlindungan dan Dimensi Hukumnya di Indonesia), Bandung : Alumni, 2003.

Departemen Pendidikan dan Kebudayaan Republik Indonesia, Kamus Besar Bahasa Indonesia Edisi Ketiga, Jakarta : Balai Pustaka, 1988. 